\title{
Beam Steering Due to Displaced Slots
}

\section{MASTER}

\author{
J. H. Whealton \\ R. W. McGaffey \\ E. F. Jaeger
}

\section{OAK RIDGE NATIONAL LABORATORY} OPERATED BY UNION CARBIDE CORPORATION - FOR THE DEPARTMENT OF ENERGY 


\section{DISCLAIMER}

This report was prepared as an account of work sponsored by an agency of the United States Government. Neither the United States Government nor any agency Thereof, nor any of their employees, makes any warranty, express or implied, or assumes any legal liability or responsibility for the accuracy, completeness, or usefulness of any information, apparatus, product, or process disclosed, or represents that its use would not infringe privately owned rights. Reference herein to any specific commercial product, process, or service by trade name, trademark, manufacturer, or otherwise does not necessarily constitute or imply its endorsement, recommendation, or favoring by the United States Government or any agency thereof. The views and opinions of authors expressed herein do not necessarily state or reflect those of the United States Government or any agency thereof. 


\section{DISCLAIMER}

Portions of this document may be illegible in electronic image products. Images are produced from the best available original document. 
Printed in the United States of America. Available from National Technical Information Servico

U.S. Department of Commerce

5285 Port Royal Road, Springfield, Virginia 22161

Price: Printed Copy $\$ 4.00$; Microfiche $\$ 3.00$

This report was prepared as an account of work sponsored by an agency of the United States Government. Neither the United States Government nor any agency thereof, nor any of their employees, contractors, subcontractors, or their employees, makes any warranty, express or implied, nor assumes any legal liability or responsibility for any third party's use or the results of such use of any information, apparatus, product or process disclosed in this report, nor represents that its use by such third party would not infringe privately owned rights. 
ORNL/TM-6944

Dist. Category UC-20

Contract No. W-7405-eng-26

FUSION ENERGY DIVISION

BEAM STEERING DUE TO DISPLACED SLOTS

J. H. Whealton

R. W. McGaffey

E. F. Jaeger

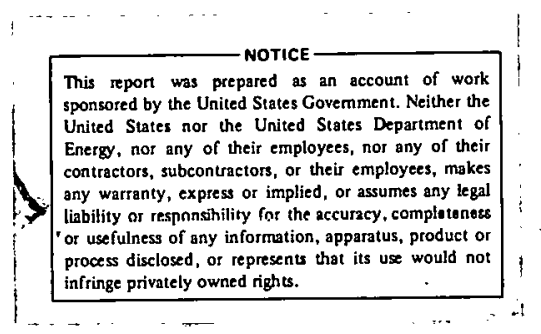

Date Published - September 1979

NOTICE This document contains information of a preliminary nature. It is subject to revision or correction and therefore does not represent a final report.

Prepared by the

OAK RIDGE NA'IIONAL LABORATORY

Oak Ridge, Tennessee. 37830 operated by UNION CARBIDE CORFUKALIIUN

for the DEPARTMENT OF ENERGY 


\section{THIS PAGE}

\section{WAS INTENTIONALLY \\ LEFT BLANK}




\begin{abstract}
Using a two-dimensional algorithm, steering of triode slots was investigated for the first time with a reasonable accounting of the ion extraction sheath.
\end{abstract}


Steering of beamlets from displaced apertures ${ }^{l}$ is an important method of providing focused ion beams. A preliminary study of triode slot displacement shows (a) no sheath influenced steering for a uniform plasma, (b) impingement mitigated steering, (c) perveance independent steering so long as there is no impingement (consistent with experimental datal), and (d) steering in excess of paraxial analysis. ${ }^{2}, 3$ These conclusions are inferred from the evidence presented in the figures. Figure 1 illustrates trajectories and equipotential contours as a function of plasma density for slots displaced by a fixed amount. Figure 2 illustrates trajectories and equipotential contours for various slot displacements at a fixed plasma density. Steering angle as a function of plasma density is shown in Fig. 3 for the slot displacement shown in Fig. 2(c). In combination with Fig. 1, Fig. 3 shows that over the range of perveance where there is no slot interception, the steering angle is independent of source plasma density. When interception occurs, the steering angle is reduced. Figure 4 shows steering angle as a function of slot displacement as deduced from Fig. 2. Also shown is the result of the linear paraxial analysis.2,3 Figure 5 shows rms divergence angle as a function of plasma density, as deduced from Fig. 1 for the slot displacement shown in Fig. 2(c). 

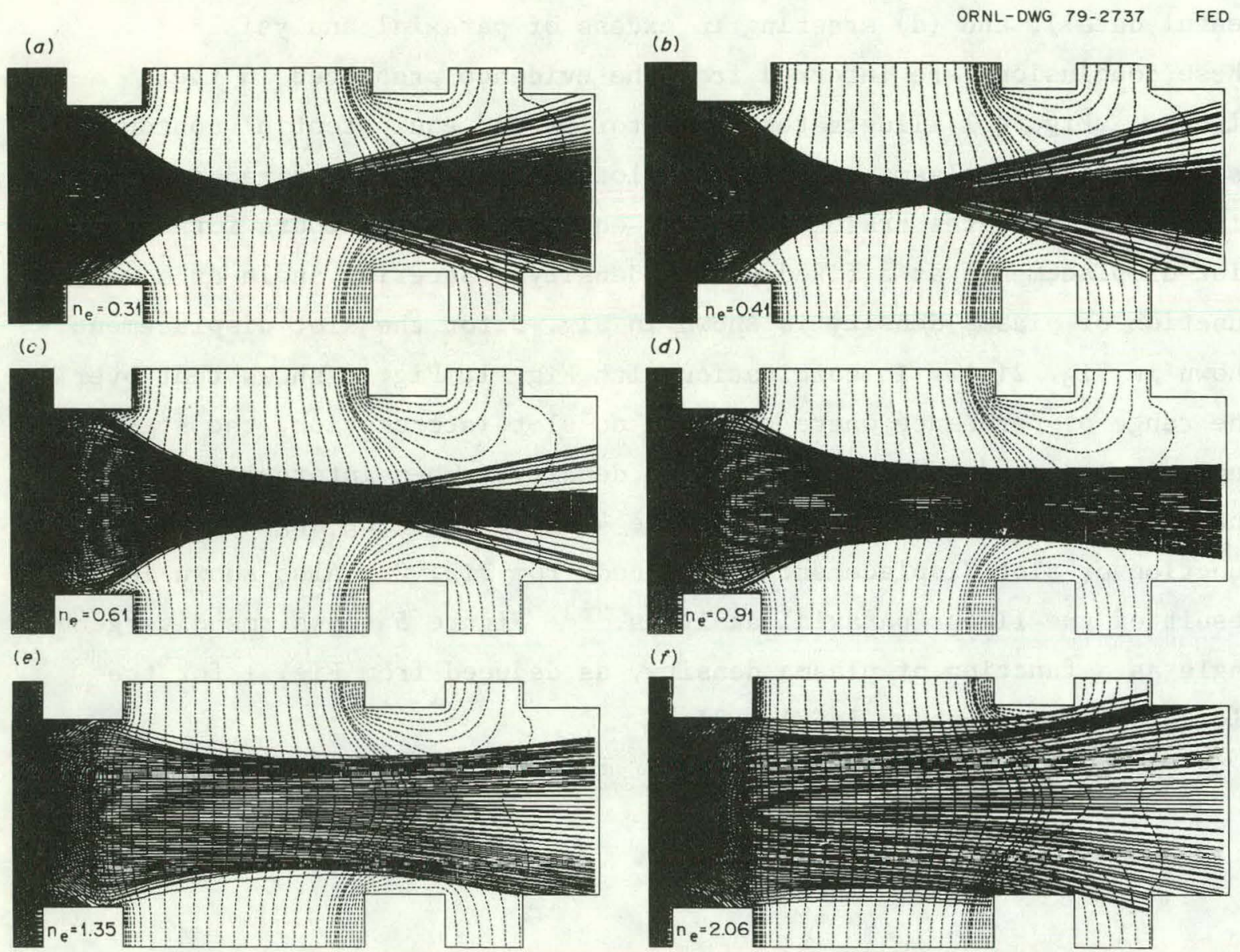

Fig. 1. Trajectories and equipotentials for six different plasma densities with a displaced slot. (a) $\mathrm{n}_{\mathrm{e}}=0.31$, (b) $\mathrm{n}_{\mathrm{e}}=0.41$, (c) $\mathrm{n}_{e}=0.61$, (d) $\mathrm{n}_{c}=0.91$, (e) $\mathrm{n}_{e}=1.35$, (f) $\mathrm{n}_{e}=2.06$ (arbitrary units). 

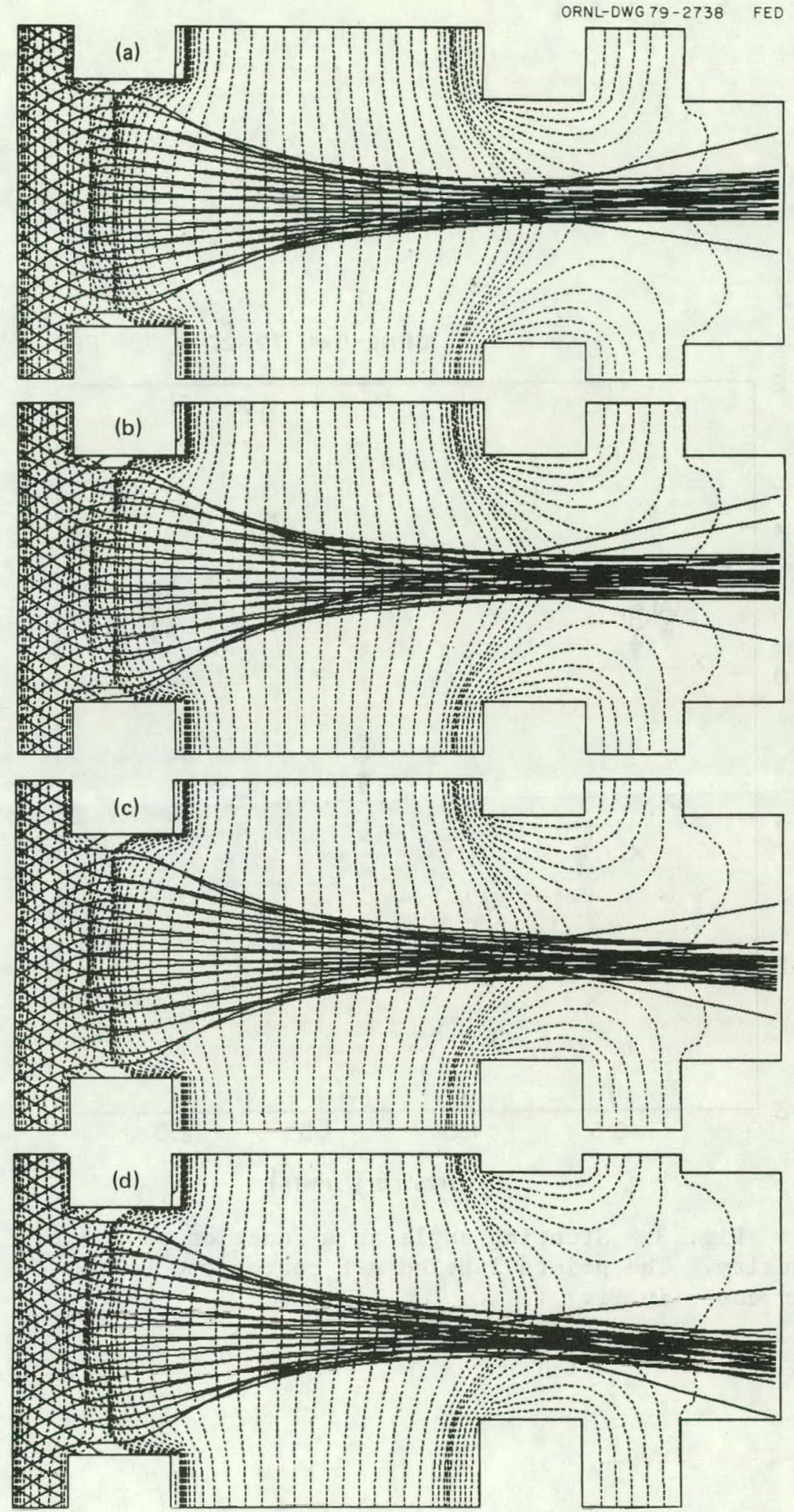

Fig. 2. Trajectories and equipotentials for various slot displacements at fixed plasma density. 


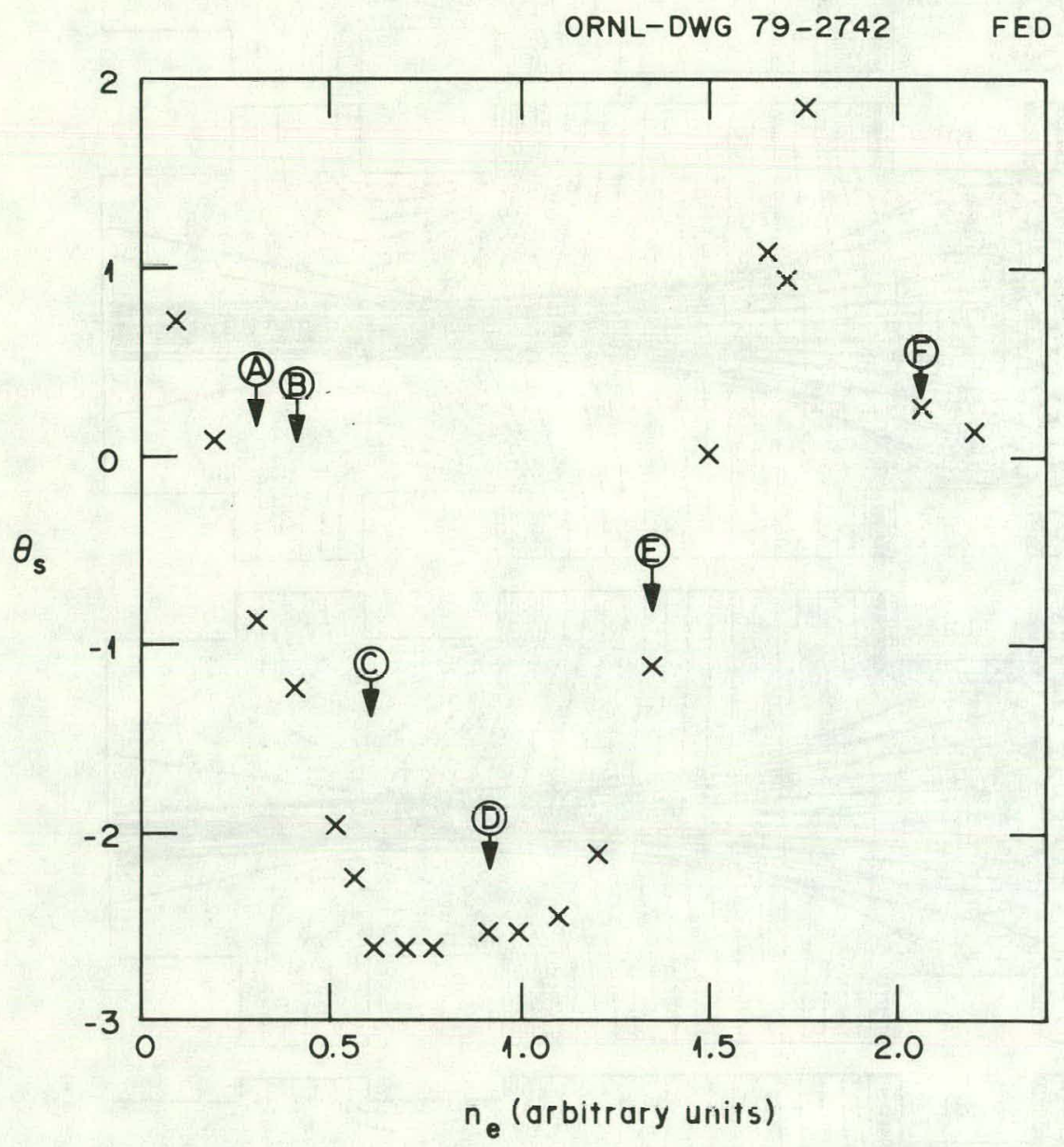

Fig. 3. Steering angle as a function of plasma density. The points labeled A-F correspond to the six cases in Fig. 1. 


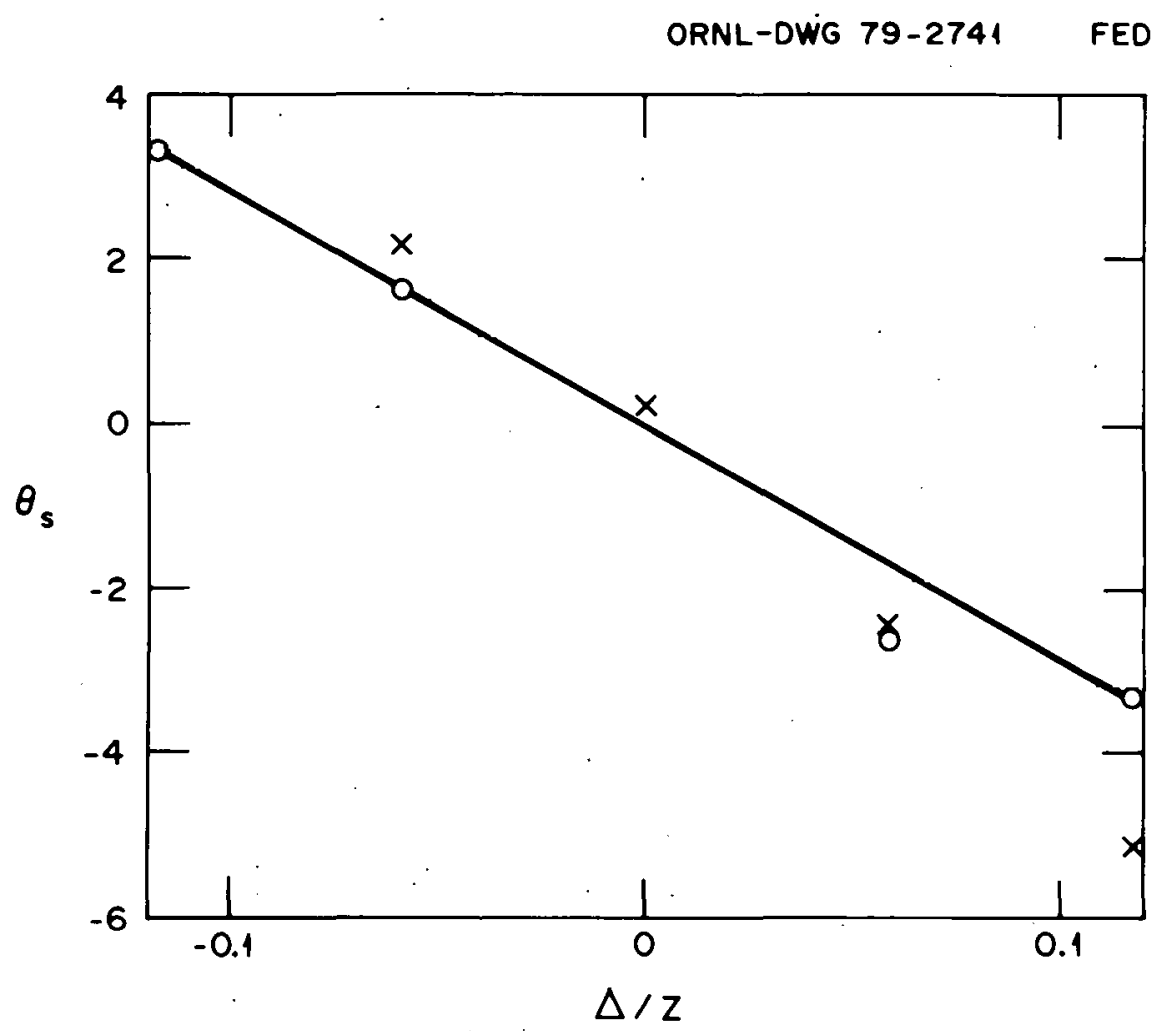

Fig. 4. Steering angle as a function of slot displacement, $\Delta$, divided by the gap distance, $Z$. The points are the computational results; the line results from a paraxial analysis. 


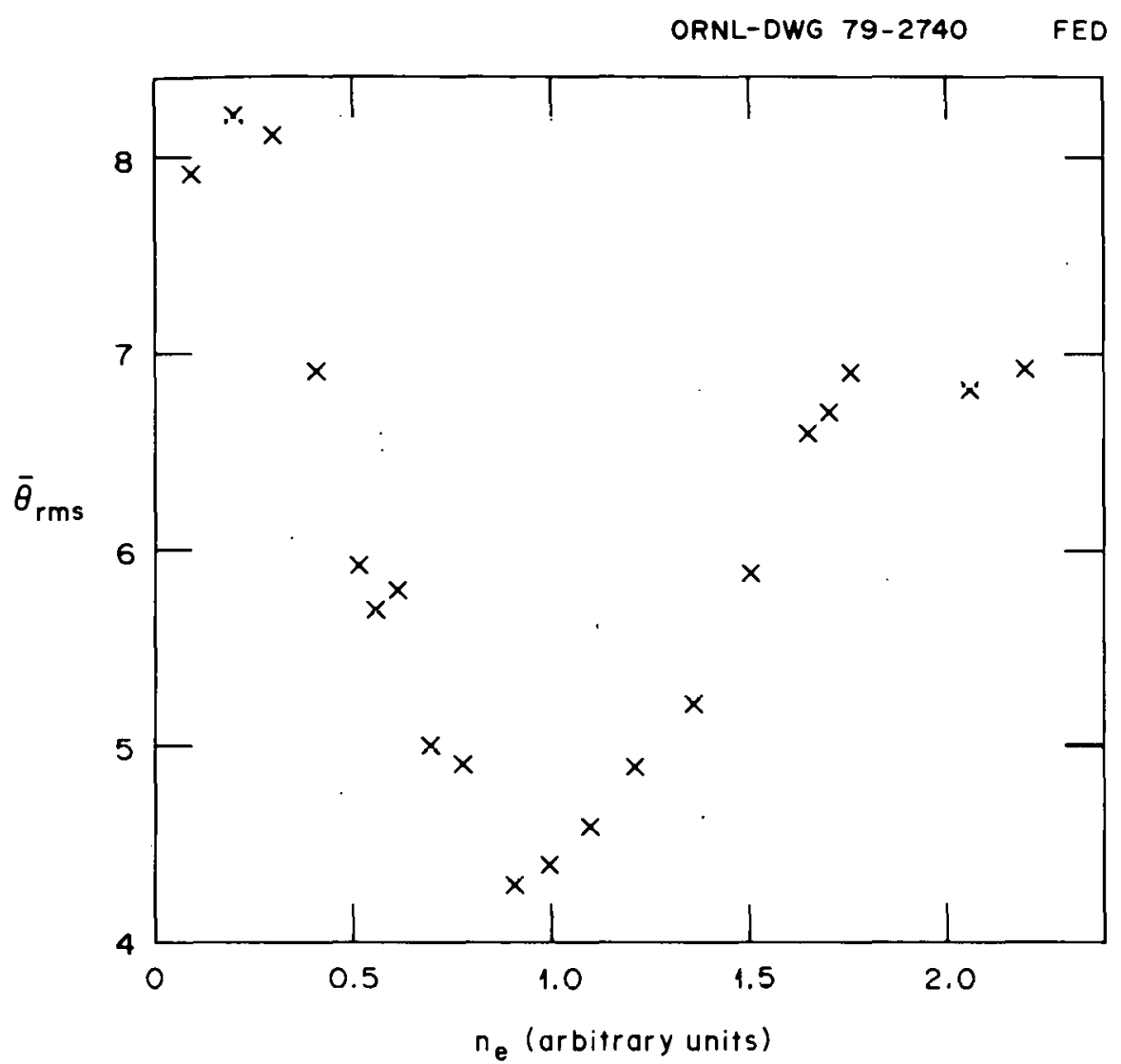

Fig. 5. Beam rms divergence angle as a function of plasma density for slot displacement shown in Fig. 2 (c). 


\section{REFERENCES}

1. L. D. Stewart, J. Kim, and S. Matsuda, Rev. Sci. Instrum. 46, 1193. (1975).

2. J. H. Whealton, Rev. Sci. Instrum. 48, 1428 (1974).

3. W. L. Gardner, J. Kim, M. M. Menon, and J. H. Whealton, Rev. Sci. Instrum. $\underline{49}, 1214$ (1978). 


\section{THIS PAGE}

WAS INTENTIONALLY

LEFT BLANK 
ORNL/TM-6944

Dist. Category UC-20

\section{INTERNAL DISTRIBUTION}

\author{
1. L. A. Berry \\ 2. J. D. Callen \\ 3. H. H. Haselton \\ 4. E. F. Jaeger \\ 5. R. W. McGaffey \\ 6. 0. B. Morgan \\ 7. M. W. Rosenthal \\ 8. J. Sheffield \\ 9-42. J. H. Whealton
}

\author{
43-44. Central Research Library \\ 45. Fusion Energy Division Library \\ 46. Fusion Energy Division \\ Communications Center \\ 47-48. Laboratory Records Department \\ 49. Laboratory Records, ORNL-RC \\ 50. ORNL Patent office \\ 51. Document Reference Section
}

\section{EXTERNAL DISTRIBUTION}

52. D. J. Anthony, Energy Systems and Technology Division, General Electric Co., Bldg. 23, Rm. 290, 1 River Rd., Schenectady, NY 12345

53. J. Bayless, Hughes Research Laboratory, 3011 Malibu Canyon Rd., Malibu, CA 90265

54. L. Bromberg, Massachusetts Institute of Technology, Cambridge, MA 02139

55. J. F. Clarke, Office of Fusion Energy, Department of Energy, Washington, DC 20545

56. F. E. Coffman, Office of Fusion Energy, Department of Energy, Washington, DC 20545

57. R. W. Conn, Department of Nuclear Engineering, University of Wisconsin, Madison, WI 53706

58. J. R. Conrad, Department of Nuclear Engineering, University of Wisconsin, Madison, WI 53706

59. W. S. Cooper, Lawrence Berkeley Laboratory, University of California, Berkeley, CA 94120

60. L. J. Drooks, Bell Telephone Laboratories, Inc., Murray Hill, NJ 07971

61. H. P. Eubank, Princeton Plasma Physics Laboratory, P.0. Box 451, Princeton, NJ 08540

62. J. H. Fink, Lawrence Livermore Laboratory, P.0. Box 808, Livermore, CA 94550

63. H. K. Forsen, Exxon Nuclear Co., 777 106th Ave., Bellevue, WA 98009

64. H. P. Furth, Princeton Plasma Physics Laboratory, P.0. Box 451, Princeton, NJ 08540

65. L. R. Grisham, Princeton Plasma Physics Laboratory, P.0. Box 451, Princeton, NJ 08540

66. R. W. Gould, California Institute of Technology, Mail Stop 116-81, Pasadena, CA 91125

67. G. Hamilton, Lawrence Livermore Laboratory, P.0. Box 808, Livermore, CA 94550 
68. R. Hamm, Los Alamos Scientific Laboratory, P.0. Box 1663, Los Alamos, NM 87544

69. R. Hiddleston, Bldg. 360ARF, Argonne National Laboratory, 9700

S. Cass Ave., Argonne, IL 60439

70. R. L. Hirsch, Exxon Research and Engineering Co., P.0. Box 101, Florham Park, NJ 07932

71. A. Holmes, Culham Laboratory, Abingdon, Oxon, OX14 3DB, United Kingdom

72. R. Huse, Public Service Eleptric and Gas Co., 80 Park Place, Newark, NJ 07101

73. N. Inoue, Department of Nuclear Engineering, Faculty of Engineering, University of Tokyo, Bunkyo-Tokyo, Japan

74. H. R. Kaufman, Colorado State University, Fort Collins, Co 80521

75. H. J. King, Hughes Research Laboratory, 3011 Malibu Canyon Rd., Malibu, CA 90265

76. C. E. Kuyatt, Surface and Electron Physics Section, Optical Physics Division, IBS, National Bureau of Standards, U.S. Department of Commerce, Washington, DC 20234

77. C. Lejeune, Université de Paris XI, Institute d'Electronique Fondamentale, 91405 Orsay Cedex, Paris, France

78. B. M. Marder, Sandia Laboratories, Alhuquerque, NM 87119

79. S. Matsuda, Japan Atomic Energy Research Institute, Tokai, Ibaraki, Japan

80. G. W. McClure, Sandia Laboratories, Albuquerque, NM 87119

81. C. Meixner, Kernforschungsanlage Jülich GmbH (KFA), Postfach 1913, 5170 Jülich 1, Federal Republic of Germany

82. A. Mensing, United Technologies Research Center, 400 Main St., East Hartford, CT 01608

83. G. H. Miley, Nuclear Engineering Program, University of Illinois, Urbana, IL 61801

84. K. Moses, Los Alamos Scientific Laboratory, P.0. Rox 1663, Los Alamos, NM 87544

85. A. Paul, Lawrrence Berkeley Laboratory, University of California, Berkeley, CA 94120

86. R. V. Pyle, Lawrence Berkeley Laboratory, University of California, Berkeley, CA 94120

87. B. H. Quon, TRW Defense and Space Systems, 1 Space Park, Redondo Beach, CA 90278

88. P. Raimbault, Centre d'Études Nucléaires. B.P. No. 6, Fontenayaux-Roses (Seine), France

89. E. A. Richley, NASA Lewis Research Center, Cleveland, OH 44135

90. T. Semac, TRW Defense and Space Systems, 1 Space Park, Redondo BCach, CA 90270

91. N. N. Semasko, I. V. Kurchatov Institute for Atomic Energy, Moscow, .USSR

92. M. R. Shabaly, Atomic Energy of Canada, Ltd., Chalk River Nuclear Laboratory, Chalk River, Ontario, Canada KOJ 1J0

93. 'I'. SLuyters, Brookhaven National Laboratory, Upton, Long Island, NY 11973

94. H. S. Staten, Office of Fusion Energy, Department of Energy, Washington, DC 20545 
95. L. D. Stewart, Princeton Plasma Physics Laboratory, P.0. Box 451, Princeton, NJ 08540

96. R. Stooksberry, Princeton Plasma Physics Laboratory, P.0. Box 451, Princeton, NJ 08540

97. E. Thompson, Culham Laboratory, Abingdon, Oxon OX14 3DB, United Kingdom

98. P. van Dine, United Technologies Research Center, 400 Main St., East Hartford, CT 01608

99. T. Williamson, Hughes Research Laboratory, 3011 Malibu Canyon Rd., Malibu, CA 90265

100. Office of the Assistant Manager, Energy Research and Development, Department of Energy, Oak Ridge Operations Office, Oak Ridge, TN 37830

101-222. Given distribution as shown in TID-4500, Magnetic Fusion Energy (Distribution Category UC-20) 